Title: Actions Taken by Public Authorities for the Equality of Women: The First Years of the United Nations

\begin{abstract}
This article will analyze some of the legal and institutional measures taken by the UN to improve women's conditions from the time it was founded until 1985. The work done by the UN is divided into two periods. The first period includes the period when women's rights were legally defended. Over those years, the United Nation's activities in favor of women consisted of promulgating declarations and conventions that sanctioned gender inequality, considering it one of the manifestations of discrimination that went against the principles of equality and dignity on which the organization based its activities. The second period began with the turn seen in 1970 with the Program of Concerted International Action for the Advancement of Women and continued with the proclamation of the United Nations International Women's Year in 1975 and the United Nations Decade for Women (19751985). In this decade three Conferences followed one another, the one that took place in Mexico (1975), Copenhagen (1980) and, finally, the one of Nairobi (1985). Although the pro-equality work of the United Nations in those years was very fruitful and of undeniable value, those efforts were not accompanied by marketing work that would provide for greater influence on international public opinion.
\end{abstract}

Keywords: gender, United Nations, equality, empowerment, conferences. 


\section{Actions Taken by Public Authorities for the Equality of Women: The First Years of the United Nations}

\section{Introduction}

The topic of gender in marketing has been of great interest for academics and professionals in this field. In fact, the first work indicating key aspects of gender differences in marketing already appeared in 1947 (Alexander, 1947) which was soon followed by work on sexual roles in advertising (Hawkins et al. 1976)

Although the role of professional women is being revalued in advertising, there have not been any relevant changes in the social stereotypes disseminated by marketing. Advertising continues insisting on sexist biases that offer a very reductionist and objectivist image of women. At the same time, the projection of negative and degrading images of women in the media does not help foster or boost equality (Eisend, 2009).

In spite of this scenario, some public organizations have been continuously establishing legal and institutional measures. And specifically, women's equality has been one of the priorities that have occupied the United Nations agenda since its foundation in 1945. There have been many achievements by this institution to improve the situation of women over these first few years. In 1975, the UN proclaimed the International Year of the Woman and after that four world conferences on women have been held. After the first one, in Mexico (1975), there was a conference in Copenhagen (1980) and one in Nairobi (1985) with the slogan "Equality, Development and Peace". The 4th World Conference in Beijing in 1995 was the last one the UN has organized to foster and ensure these improvements.

Given the broad scope of the field of study and the numerous legal and institutional measures taken by the United Nations to improve the conditions of women, this article will only analyze the first years of history of this institution during which the foundation was laid for the Beijing "Platform for Action". Therefore, all of the actions that have been taken from 1945 to 1985, the date of the Nairobi Conference, will be studied. 1995 began a new period with the celebration of the 4th World Conference on Women and the subsequent monitoring sessions that have been organized since the year 2000. The relevance and change that came with Beijing was of such scope that it is deserving of a separate chapter meaning it is not included in this research.

There are no serious references for the work done by the United Nations over those first years with respect to the media as far as how it influences the image of women throughout the world. It was only after 1975, at the Mexico Conference, when this top was specifically approached for the first time. The Mexico World Plan for Action recognized the importance of communication and information in improving the conditions of women. Paragraphs 83 to 91 establish measures relating to education and the distribution of information. They particularly focused on the sexist image shown of women and emphasized the importance of women's active participation in decision making in the media. Finally, it 
was made clear that there was a need to initiate educational programs to eliminate prejudices which limit the participation of women in society (Women's Institute, 1993).

One relevant data is that the Beijing Conference had more coverage than the three preceding conferences combined which confirms the little media impact of the earlier conferences. Although it is true that the issue of women and the media was more closely handled in Nairobi than at the previous conferences, it wasn't until the Beijing Conference when the topic was truly approached in depth with unprecedented importance (Lara, 1995).

Even though, as can be observed throughout this article, the work of the UN has been laudable and a relentless fight for equality between men and women, it is also true that over its first few years this international organization was not known for launching marketing campaigns that mobilized public opinion towards promoting this equality. It is undeniable that the United Nations has fostered such campaigns and that they have been increased over the years, leaving a mark on society; but, just as the fight for the establishment of legal and institutional measures have occupied part of the work of the institution, the campaign to "sell" them was not as fruitful as would have been expected during the first few years (Women's Institute, 2003).

\section{United Nations Actions for Gender Equality 1945-1985}

\subsection{First Period (1945-1970)}

The 1945 UN Foundational Charter describes equality between men and women as one of the ideological principles underlying its activities and states a will to guarantee access to positions and offices under equal conditions for both sexes. Later on, the Universal Declaration of Human Rights, adopted by the United Nations in 1948, reiterated the organization's commitment in favor of equality among people without any gender-based distinctions. This document, which has been used as a reference for later generations, specifies that the human rights and fundamental liberties outlined therein pertained to all people without any distinction based on race, color, sex, language, religion, political or any other type of opinion, national or social origin, economic position, birth or any other condition (United Nations, 1948). These proclamations marked the start of inter-governmental actions to defend women.

The first United Nations authority dedicated to defending the conditions of women was founded in 1946. Currently comprised of 45 Member States, the Commission on the Status of Women was created by the Economic and Social Council with two objectives: first, to prepare recommendations and reports aimed at guaranteeing women's rights under equal conditions as men in political, economic, social and educational arenas; and, secondly, to submit recommendations on urgent problems. The Commission issued a recommendation during its first period of sessions in 1947, by which the Council expanded its functions to add women's civil rights to its working agenda (Pietila, 1995). 
The Commission on the Status of Women developed the following legal instruments in the decades of the 1950s and 1960s: The Convention on the Political Rights of Women, approved by the UN General Assembly in 1951; the Convention on the Nationality of Married Women, which was approved in 1957; as well as the Conventions and Recommendations on Consent to Marriage, the Minimum Age for Marriage and Registration of Marriages, approved in 1962 and 1965. Another one was the Declaration on the Elimination of Discrimination against Women in 1967. This declaration was the predecessor of the Convention on the Elimination of All Forms of Discrimination against Women, which was signed in 1979, discussed below.

Thanks to Art. 71 of the United Nations Charter, which establishes the consultative status of non-governmental organizations (NGOs) in the Social and Economic Council, the Commission on the Status of Women has benefitted from the contributions of organized women's groups since the very beginning. The influence of women's NGOs increased incredibly during the decade of the 1990s and the 4th World Conference on Women in 1995, with more and more space dedicated in both their deliberations and decisions.

It must be noted that the activity of women's movements began in the inter-governmental arena much before the creation of the United Nations. Women gathered at what could be called the "First Parallel Forum for NGOs" in 1919 at the Foundational Summit of the League of Nations. Over the following two decades, international women's non-governmental organizations multiplied their contacts with the League of Nations, putting pressure on the government delegations present at several summits on such essential topics for them as healthcare, education, peace and disarmament, although without any adequate legal or institutional framework (Miller and Razavi 1995).

It was in the area of workers' rights where women in the non-governmental arena saw their earliest participation in the production of resolutions, conventions and international declarations through the International Labor Organization (ILO).

Constituted in 1919 at the same time as the League of Nations and included in the United Nations system in 1945, the ILO is a mixed organization comprised by 50\% government representatives and $25 \%$ employer representatives. The remaining fourth is made up of workers' representatives. This unique representativeness opened up a place for the participation of workers within the very ILO.

The two objectives pursued by the ILO from the very beginning in relation to women workers were protecting their role as mothers and promoting equality between men and women in the workplace. Both the topics as well as the content of the conventions and resolutions issued by the ILO have evolved from mere protection from a healthcare and reproductive perspective towards the adoption of measures aimed at equal job conditions and opportunities (Gaudier, 1994).

The following conventions were promulgated between the years 1919 and 1970 . The Maternity Protection Convention (1919), which was revised in 1952, the Convention concerning Employment of Women during the Night (1919), which was revised in 1948, the Convention concerning the Employment of Women on Underground Work (1935), the Convention concerning on Equal Remuneration for Men and Women Workers for Work of Equal Value (1951), the Convention concerning Discrimination in respect of Employment (1958), the Convention concerning Vocational 
Training (1962), the Convention concerning Employment Policy (1964), and the Convention on Employment for Women with Family Responsibilities (1965).

In 1966, the UN approved two International Human Rights Covenants applicable to both men and women. They were: the International Covenant on Civil and Political Rights and the International Covenant on Economic, Social and Cultural Rights. The covenants (which entered into force in 1976) reinforced the Universal Declaration as they implemented the rights outlined therein, converting them into legal obligations for the governments of the countries that ratified them or adhered to them.

Compared with the 1948 Human Rights Declaration, the wording of these texts offers a greater emphasis on the principle of equality between men and women. Whereas the Human Rights Declaration mentioned sex-based discrimination among other types of discrimination such as race and religion, the International Covenant of Civil and Political Rights and the one on Economic, Social and Cultural Rights dedicated an entire article to underlining equality between men and women as part of the enjoyment of these rights. Among the rights proclaimed in the first Covenant are the right to marry in respect of the legal minimum age, consent between husbands and wives and equal rights and responsibilities for both spouses in marriage during and after the dissolution thereof. It also reiterated the right to vote and occupy public office as established in the 1951 Convention on the Political Rights of Women.

During the first period (1945-1970), the status of the woman was essentially considered by the UN as a legal area of concern. The basic demands were access to education, healthcare services, food, work under dignified wage and health conditions etc. (Hernández Zubizarreta, 1999).

Over the years, the United Nations gradually recognized and expanded women's rights in the civil, political, economic, educational and employment arenas. Nonetheless, the UN did not consider during this first era the causes of the inequalities that half of all humanity continued to suffer just because they were women. Their marginalization in decision-making, lack of power, or the roles that had been established for men and women in society, did not have a place on the United Nations agenda at that time.

But, the truth is that during this first period there were some early examples of another view of the feminine issue where women stopped being passive beneficiaries of development and vulnerable people with rights to be protected to be seen as active agents of economic and social development within the population (Vázquez and Villalba, 1997). It was at the end of the 1960s when the international community began a substantial change that would affect its strategy on issues relating to the promotion of women based on their integration in development processes.

The new perspective which arose for the treatment of issues relating to women was known as the "WID approach" -as in "Women in Development"-. On the one hand, this proved the magnitude of the impact of sub-development on women, defining them as "the poorest of the poor" (Hernández Zubizarreta, 1999). And, on the other hand, it underlined the importance of their participation in the economic life of human communities.

\subsection{Second Period (1970-1985)}




\section{5: 1st World Conference in Mexico.}

The year 1975 was chosen by the United Nations as the International Women's Year. That same year, the first World Conference on Women was organized in Mexico City. With these measures, the year 1975 marked a milestone in the promotion of equality between men and women.

Stock was taken that year of the 30 years of UN activity in the area of promoting women with rather unsatisfactory results. The Organization itself had to acknowledge that its essentially legal activity had not brought about many results as concerned the status of women in the world.

One of the major achievements of the International Women's Year World Conference was the beginning of world-wide dialogue on equality between men and women. For the first time ever, the UN Member States were gathering and debating the agreed goals in the area of gender equality, identifying obstacles and designing specific strategies to achieve them.

Although initiatives had been developed in some countries concerning the advancement of women by increasing their participation in politics, economics and social affairs, the Mexican Conference made it so these isolated advances could find a platform for institutional reinforcement as well as global-wide implementation. The International Women's Year World Conference recognized the urgency of improving the situation of women and finding more effective methods and strategies that would equip them to have the same opportunities as men when it came to actively participating in the development of their countries and contributing to the achievement of world peace. It urged the States to make the necessary changes in their economic and social policies (Women's Institute, 1993).

As a result of the World Conference in Mexico, the 133 participating States jointly defined a World Plan for Action aimed at intensifying measures to promote full equality between men and women.

The World Plan for Action that came out of the Mexico Conference not only proposed equality but also the goal of women's full integration in all efforts in favor of development. One of the goals to be achieved was to increase women's contributions to strengthening world peace. Women began to be considered in Mexico not only as passive victims of situations of underdevelopment and conflict but as active agents of the development and peace processes.

The goals of Equality, Development and Peace became the slogan of the United Nations Decade for Women, declared by the UN at the request of the Conference for the 1976-1985 period. The World Plan for Action defined the fundamental goals of Equality, Development and Peace and urged the governments of the signatory States to implement the necessary measures to meet these goals by the end of the Decade for Women nationally, regionally and internationally. With an aim to ensuring success, 14 minimum goals were set for the first half of the period. They were as follows: the promotion of education and equal access on all levels, underlining the mandatory nature of primary education; the reduction of unemployment rates among women; healthcare; equality in the exercise of civil rights and the presence of women in local, national and international decision-making bodies (Solana et al. 1997). The UN Member States were to meet in 1980 in Copenhagen to assess the degree of achievement of these intermediate goals.

Following the Mexico Conference, the UN established two new bodies aimed at guaranteeing the achievement of the Decade for Women goals. One was the International Research and Training 
Institute for the Advancement of Women (INSTRAW), the objective of which was to simulate the advancement of women and their contribution to development through research, training and the dissemination of information (López and Sierra, 2002). The other was the United Nations Development Fund for Women (UNIFEM), which was to be used as financial support and technical assistance for programs promoting women's human rights and gender equality (United Nations, 2000). These bodies, which have been doing extremely relevant work to improve the status of women in the world since their creation, joined the pre-existing Subdivision (now, Division) for the Advancement of Women of the Department of Economic and Social Affairs under the UN Secretary General, which was created to support the Commission on the Status of Women.

The participation of women themselves in the debates and in the definition of the guidelines is another achievement to be highlighted from this Conference. Of the 133 delegations present, 113 were led by women. In addition, some 4000 women were able to attend the Women's Year Conference thanks to the tribunals brought in by various NGOs (Women's Institute, 1993).

\section{9: The Convention to Eliminate All Forms of Discrimination against Women.}

In December 1979, the UN General Assembly approved the Convention to Eliminate All Forms of Discrimination against Women. This document and, now, this Convention binds 176 States which upon signing it agreed to have their laws and practices related to women's rights examined by the Committee on the Elimination of Discrimination Against Women.

The Convention to Eliminate All Forms of Discrimination against Women itemizes throughout its 30 articles the measures that must be implemented to progressively eradicate all forms of discrimination against women in the political and public arenas, education, employment, healthcare, marriage, family and due to nationality. It is a compendium of all of the efforts made within the United Nations to incorporate the principles of gender equality in national laws. It is specially fed by the Plan developed by the Commission on the Status of Women for the Decade and the Declaration that came out of the First World Conference on Women in Mexico. It explicitly lists the following acknowledgements: the essential nature of wellbeing and peace for real development; the need for greater participation by women in all spheres of society; the urgent need to modify the traditional role of both men and women in society and the family; and the shared responsibility of both in the education of their children (Women's Institute, 1995).

\section{0: 2nd World Conference in Copenhagen.}

In Copenhagen, 145 States gathered to analyze the degree of achievement of the goals established by the World Plan for Action that came out of the Conference in Mexico. This review made it possible to observe how although progress had been made towards achieving some of the goals, the implementation of legal equality between men and women had not seen the development expected as it had not been reflected in any real exercise of equal rights due to obstacles such as: an insufficient political will, a failure to recognize the value of women's contributions to society, the scarce number of women in decision-making positions, insufficient services so they could perform their duties in 
national life, the lack of credit facilities, the scarce financial resources in general, the lack of participation of men in improving the role of women in society, the scarce awareness among women themselves with respect to the opportunities available, among others. In an effort to make it easier for women to exercise their legal rights, governments were asked to try to eliminate these obstacles. Three areas were established where the signatory States and UN Agencies would have to concentrate their efforts in order to achieve the goals of the World Plan for Action during a five year period. They were: equal access to education, equal employment opportunities and adequate healthcare.

The General Assembly approved the Plan for Action for the second half of the United Nations Decade for Women in Copenhagen. By means of this document, the signatory States undertook to increase national measures to guarantee women's rights to ownership and control of assets in general, the right to inherit, parental authority and nationality. At the same time, the stereotypical images of women would be fought by the governments.

The resistance of certain official delegations towards to the content of the recommendations, which were incompatible in a number of cases with national law and with some of the deeply-rooted cultural principles in their societies, made it difficult to obtain a consensus. The political tensions that had been seen at the Mexico Conference were made even clearer. Such is the case that some deliberations absolutely failed and the final document was approved without the consensus of all of the participating States.

The international situation and political issues considerably influenced all of the Women's Conferences as the main controversies in Nairobi had more to do with the political trends existing at that time in the world than any progress in women's own thoughts about their status. Therefore, the main issues were apartheid and the situation the issue in South Africa, disarmament, the effects of structural adjustment, debt and the Palestine affair. (...) However, the Nairobi miracle was achieving total consensus and, despite all prognoses, women's concerns for their own problems led to obtaining the necessary commitments to approve the political strategy document (Vázquez and Villalba, 1997).

\section{5: 3rd World Conference in Nairobi.}

The 3rd United Nations World Conference was held in Nairobi (Kenya). The group of participating countries had expanded over the decade going from 133 in Mexico to 157 in Nairobi. Through the movement towards gender equality, international civil society had benefitted from the dissemination work performed by the UN over the decade that was ending with the Nairobi Conference. Proof of this was the presence of 15,000 representatives from NGOs at the parallel forum of non-governmental organizations.

The Nairobi Strategies articulated three areas: Equality, Development and Peace. This document identified the obstacles found in the achievement of the goals defined at the beginning of the decade and basic strategies were designed for the future as well as the necessary measures to be applied nationally. In the area of Development, added to the sub-topics relating to employment, health and education that were defined in Mexico were topics such as food, water and agriculture, industry, trade and commercial services, science and technology, communications, housing, settlements, development and transport, energy, the environment and social services. In the area of health, special sections were 
dedicated to women and children under apartheid, Palestine women and children, and women in areas affected by armed conflicts, foreign intervention and threats to peace. Moreover, the document developed recommendations in areas of special interest: women in areas affected by drought, poor women in cities, elderly women, young women, abused women, poverty-stricken women, women as victims of human trafficking and involuntary prostitution, women deprived of traditional means of survival, women as the only support for their family, women with physical or mental disabilities, women in prison and subject to criminal law, refugee and displaced women and children, women emigrants and women belonging to minorities as well as indigenous women. The final chapter dealt with international and regional cooperation and stipulated measures that needed to be implemented in the United Nations system in the areas of monitoring, technical cooperation services, training and consulting, institutional coordination, research and policy analysis, the participation of women in international and regional activities, and in decision-making and the dissemination of information (Women's Institute, 1987).

The document Nairobi Forward-looking Strategies for the Advancement of Women stated that the decade's goals and objectives had only been partially achieved. Although the first few years of the decade were marked by relatively positive economic conditions in developed and developing countries, the later deterioration of the economic situation made it so the pace of the efforts aimed at promoting women's participation in society under conditions of equality was reduced and new problems arose.

The Nairobi Conference emphasized the existing relationship between the impoverishment of developing countries and the recessive economic and social policies they are subject to through structural adjustment programs, on the one hand, and the stall that this economic situation caused as concerned the adoption of measures to promote gender equality in these national contexts, on the other.

The final Nairobi document, entitled "Nairobi Forward-looking Strategies for the Advancement of Women until the Year 2000" introduced such change in the approach taken by the UN in relation to the issue of the status of women that the organization itself referred to this Conference as the "birth of world-wide feminism". For the first time ever, a document approved by total consensus of all of the participating States went into the cultural reasons that perpetuated sex-based inequality and recommended that these obstacles be eliminated not only through laws but also by educating the general population.

Equality in the Nairobi Strategies was no longer exclusively approached in terms of nondiscrimination of women but rather the signatory States undertook to implement legal and institutional mechanisms that would lead to the full participation of women in all occupations, especially in areas that had been traditionally considered exclusive to men in order to eliminate the occupational barriers and taboos (Vázquez and Villalba, 1997). It emphasized the adoption of measures aimed at ensuring equal representation of men and women in decision-making bodies on all political levels - local, national and inter-governmental. The fact that this Conference no longer treated equality in terms of "non-discrimination" but rather as the participation of women in all social arenas was a significant qualitative turn given that it would lead to structural changes in society where women were to be considered active agents of this transformation. Another aspect to be highlighted is that at this 
Conference, the cultural reasons that perpetuated sex-based inequality among people were discussed in depth and the conclusion was that there are no physiological reasons to consider a women of lower status than a man nor are there any specifically feminine jobs or tasks (Women's Institute, 1987).

The Nairobi Strategies proved the need to intensify research into the status of women and the causes for their discrimination in order to begin analyzing gender in laws and specific and general policies both in the national as well as regional and international scenarios (Hijab and Lewis, 2003).

It was in the Nairobi Strategies that, without specifically naming it, the "empowerment" approach was outlined; in other words, the need to advocate self-esteem, autonomy and greater access to power in women. Although the concept of "empowerment" impregnates the Nairobi Strategies, the word only appeared for the first time seven years later at the Conference on Population and Development in El Cairo (Minguez, 1997), and was later included in the Beijing Declaration in 1995.

Another topic emphasized was the insistence on the establishment of measures in all spheres of life - family, neighborhoods, national and international against gender violence. Violence against women was defined for the first time ever as "a fundamental obstacle to the achievement of peace and other goals for the Decade" and it was granted the status of an area of specific concern (Women's Institute, 1987).

In the non-governmental arena, an Observatory on International Action for Women's Rights was created in Nairobi to monitor the Convention to Eliminate All Forms of Discrimination against Women.

It is at the this Conference, ofthe Chapter of Development where the studies and actions are specified both by the Government and the United Nations System to facilitate the elimination of the stereotypes in the media and the incorporation of women in society. In this document, we can already find the implementation of studies, the development of programs and the allocation of resources to support national campaigns aimed to raise public awareness of the need of equality between men and women.

Although the issue of women and the means of communication has been addressed in more depth in Nairobi, it is in the Beijing Conference where the issue has been actually attended in depth giving it an importance without precedent.

\section{Towards equality in Marketing}

Despite the efforts at the United Nations in its first few years to achieve genuine equality between men and women, it appears that there has been no significant change as in the image of woman in the mass media and in marketing. However, it is true that all the measures that have been taken have favored grater presence of women in the public sphere, which has had a social impact even in the consumption sector and the market. As various researchers have said, the phenomenon of woman in the labor sector has probably hade a greater impact on Marketing than any other social change. This is due to the fact that women are working and saving more than men and this leads to industries considering the marketing sector oriented to women (Lamb, Hair and McDaniel, 2008). 
As proof of the precious statement, in some Anglo-Saxon countries there has already started a phenomenon of analyzing terms of trade taking into account the gender as a variable. In fact, in 1991 the Association of Consumer Research (ACR) convoked the first conference on gender, marketing and consumption. Actually, up to date, numerous conferences have taken place in which the issues such as gender identity, consumption differences between men and women, sociocultural dimensions of consumption of men and woman's behavior, as well as life styles and rituals of consumption have been developed in depth; as well the queer theory (Dema, 2007)

The gender variable, in the marketing sector has opened new research routes. As Sandra Dema pointed out, if we want to reach all humanity without excluding more than half of the population, we must incorporate women to the analysis of the trade terms taking into account their points of view. This is due to the fat that these points of views can differ to the dominants and develop into a new branch of thought on new methods, as well as new approaches and tools more related to the new study object.

Nevertheless, we can sustain that there is still a long way to overcome the traditional Marketing trends that preserved an all-male perspective and consigned woman to oblivion. Modern day marketing in unable to maintain an old standpoint of the world. It cannot fall behind in the advances of society, that is why it has to be inclusive and comprehensive in gender perspective by involving women in all-sales strategies.

\section{Conclusions}

This article analyzed the initial work done by the United Nations to foster and improve the conditions of women. In the first 40 years, this effort was mainly known for implementing essentially legal measures. Thus, the fight in the beginning focused on the recognition of women's political, employment, civil, educational and economic rights and left the causes of inequality to the side. At the end of the 1960s, the international community began a change of approach and women were included in the processes of global change and development.

After 1975 and the adoption of a number of legal and institutional measures, the UN's work was essentially aimed at proclaiming the International Women's Year and on holding three international conferences that would lead to a significant step as far as improving the status of women all over the world. Never before had the Member States gathered together and agreed to specific goals and actions in the area of gender equality. The Nairobi Conference marked a milestone in history as for the first time ever, women were considered as active agents of the change and not just as mere spectators.

This effort by the UN has not seen the media repercussions expected. Despite the changes made, the image transmitted of women continues to be reductionist and loaded with sexist stereotypes (Lundstrom et al., 1997). In fact, some products and their acquisition/use are associated with male or female images that are not based on any biological reasoning but rather certain stereotypes (Gainer, 1993). For example, the decision to buy a car is mostly related to men and decisions regarding 
household furniture is more associated with women. In spite of the ongoing efforts in various areas of society for gender equality, the fact that, to date, gender continues to be a widely used variable in marketing along with other demographic variables in order to explain behaviors or segment the market cannot be denied.

In the beginning, the United Nations focused more on legislative measures than on the objectivist view the media and advertising transmitted of women. It was in 1975, at the Mexico Conference, when greater importance was given to the topic and it was specifically approached. But it wasn't until 1995 in Beijing when the first indications of real and effective change promoting an image of women as agents and beneficiaries of development began to be perceived.

Politicians and companies still have a lot to do to adapt the legislative frameworks that are being established with great effort by the UN in a view to equality. This means establishing more permeable relational mechanisms between them: integrating marketing information in the decisionmaking process of public authorities and including more social approaches in marketing practices (Cervera et al. 2000).

\section{References}

Alexander, R. S (1947). Some aspects of sex differences in relation to marketing. Journal of Marketing, $12,158-172$.

Cervera, A.; Calderón, H. Mollá, A (1999) Market orientation: A framework for Public Institutions. Journal of Non Profit and Public Sector Marketing. Vol. 7, 1, pgs. 3-24.

Dema Moreno, S, (1997). La introducción de la perspectiva de género en el marketing: una nueva forma de analizar las relaciones de intercambio. Estudios sobre consumo 81, pgs 55-69.

Eisend, M (2009) A meta-analysis of gender roles in advertising. Journal of the Academy of Marketing Science, 38, 418-440.

Gaudier, M (1994) The development of the women's questions at the ILO 1919-1994, 75 years of progress toward equality, Labor Institutions and Development Program .

Gainer (1993), "An empirical investigation of the role of involvement with a gendered product", Psychology and Marketing, Vol.10, n4, pgs.265-283.

Hawkins, D. I, Coney, K. A. (1976). Advertising and differentiated sex roles in contemporary American society. Academy of Marketing Science Journal, 4(1), 418-429.

Hernández Zubizarreta, I (1999) Desigualdad de género en desarrollo, in Villota, P., Globalización y Género, Synthesis, Madrid.

Hijab, N. and Lewis, $K$ (2003) Transforming the mainstreaming, Gender in UNDP, New York, September.

Karl, M (2001) Women and empowerment: participation and decision-making, Zed Publishers, London, 1994, in Directrices y guía de conceptos del CAD sobre la igualdad entre mujeres y hombres, Spanish Ministry of Foreign Affairs, Secretary of State for International Cooperation and Iberoamerica, Madrid, 2nd edition.

Lamb, C., Hair, J. y McDaniel, C. (2008). Marketing. Ohio:Cengage Learning. 
Lara, P (1995) Notas sobre la IV Conferencia Mundial de las Mujeres, Fundación Promoción Social de la Cultura, Madrid.

López Méndez, I, Sierra Legina, B (2001) Integrando el análisis de género en el desarrollo: manual para técnicos de la cooperación, University Institute for Development and Cooperation, Madrid.

Lundstrom, W. J. and Sciglimpaglia (1977) Sex Role Portrayals in Advertising. Journal of Marketing, 41 (July). 72-79.

Miller, C, Razavi, S (1995) Gender mainstreaming: a study of efforts by the UNDP, the world bank and the ILO to institutionalize gender issues, UNRISD Occasional Paper 4, Fourth World Conference on Women.

Miller, C, Razavi, S (1995) From WID to GAD: conceptual shifts in the women and development discourse, UNRISD Occasional Paper 1, UN Fourth World Conference on Women.

Pietila, H (1995) Mostrando la importancia de las mujeres, in Martínez López, C. (editora), Feminismo, Ciencia y Transformación social, Universidad de Granada, Instituto de Estudios de la Mujer, col. Feminae.

Pietila, H (2002) Engendering the Global Agenda: The Story of Women and the United Nations, Geneva, NGLS.

Spanish Women's Institute (1987). Nairobi Forward-looking Strategies for the Advancement of Women, Madrid.

Spanish Women's Institute (1993) The Four United Nations World Conferences on Women, Madrid.

Spanish Women's Institute (1995) Convention to Eliminate All Forms of Discrimination against Women and Recommendations, Madrid.

Spanish Women's Institute (2003) 4th Plan for Equal Opportunities between Women and Men, 2003 2006, Madrid.

Solana, Y., Rodríguez, R., Rodríguez, I. and Santiago, P (1997) La larga marcha hacía la igualdad: IV conferencia mundial sobre las mujeres, Pekín 95, evaluación del proceso en España, Spanish Ministry of Labor and Social Affairs, Women's Institute, Madrid.

United Nations (1948) Universal Declaration of Human Rights.

United Nations (1960) Convention Against Discrimination in Education.

United Nations (2000) $A B C^{\prime}$ 's of the United Nations, Department of Public Information, New York.

United Nations (2000) Adoption of Measures in Favor of Gender Equality and the Advancement of Women, Women 2000, New York.

United Nations (1986), Communication in service to women, a document prepared for the World Conference to Examine and Appraise the Achievements of the United Nations Decade for Women, Nairobi, 15-26 July 1985, Paris, United Nations Educational, Scientific and Cultural Organization.

Vázquez, M. and Villalba, Ma.R (1997), La mujer en el mundo de hoy, situación y políticas de los gobiernos (Beijing 1995), Escuela Libre, Madrid. 